\title{
Examination of the Effective Factors on the Performances of the Recreational Trap Shooters: An Amateur Competition Sample in Afyonkarahisar City
}

\author{
Şeniz KARAGÖZ ${ }^{1}$ Sinan SARAÇLI ${ }^{2}$ Halime DİNÇ ${ }^{3}$ Berkalp TUNCA $^{4}$
}

\begin{abstract}
The purpose of this study was to investigate the effective factors on the performances of recreational trap shooters. With this purpose, the data set including demographic and shooting features/styles of amateur trap shooters were obtained via a questionnaire. As the rule of the competition, performances of shooters are measured over ten shots and the performance results are obtained from the arbitrator reports at the end of the competition. To determine the effects of the demographic and shooting styles on the performances of competitors Chi-Square Based multivariable statistical analysis CHAID analysis is used. Related to the results of CHAID analysis, to determine the relations among the most effective variables, we applied Multiple Correspondence Analysis. The results of the statistical analysis indicate that the most important variable on the performances of trap shooters is the alcohol usage of the trap shooters among others (experience, height, and etc.), and trap shooters whose performances are categorized as high are those who use alcohol, has less than 7+ years experience, using both of eyes and left hand.
\end{abstract}

Keywords: Trap Shooting, Trap Performance, Multivariate Statistical Analysis.

\section{Rekreasyonel Trap Atıcıların Performanslarma Etki Eden Faktörlerin İncelenmesi: Afyonkarahisar İli Amatör Müsabaka Örneği}

$\ddot{O} z$

$\mathrm{Bu}$ çalışmanın amacı, rekreatif trap atıcılarının performansları üzerine etkili olan faktörleri araştırmaktır. $\mathrm{Bu}$ amaçla amatör trap atıcılarının demografik ve atış özelliklerini/tarzlarını içeren veri seti anket yoluyla elde edilmiştir. Müsabaka kuralı olarak, atıcıların performansları on atış üzerinden ölçüldü ve müsabaka sonunda hakem raporlarından performans sonuçları alındı. Demografik ve atış tarzlarının rakiplerinin performansları üzerindeki etkilerini belirlemek için Ki-Kare tabanlı çok değişkenli istatistiksel analiz olan CHAID analizi kullanıldı. CHAID analizi sonuçlarıyla ilgili olarak en etkili değişkenler arasındaki ilişkileri belirlemek için Çoklu Uyum Analizi uygulandı. İstatistiksel analiz sonuçları, trap atıcılarının performansları üzerindeki en önemli değişkenin, diğer değişkenlere kıyasla (deneyim, boy, vb.) alkol kullanımı olduğunu ortaya koydu ve performansları yüksek olarak sınıflandırılan trap atıcılarının alkol kullanan, 7 yıldan az deneyime sahip, her iki gözünü ve sol elini kullananlar olduğu belirlendi.

Anahtar Kelimeler: Trap Atışı, Trap Performansı, Çok Değişkenli İstatistiksel Analiz.

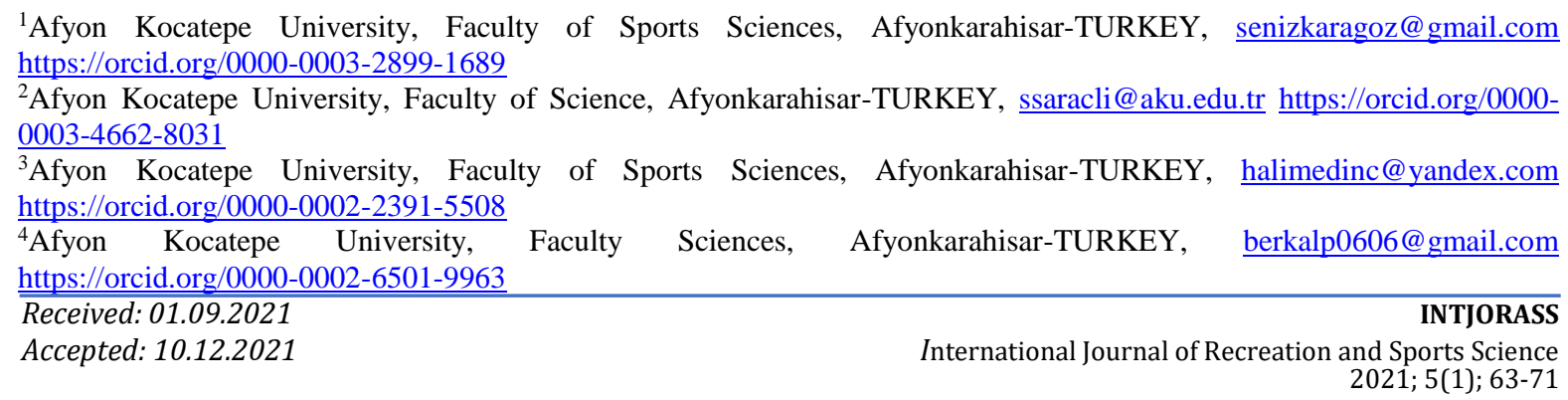


Karagöz Ş., Saraçlı S., Dinç H. \& Tunca B. (2021). Examination of the Effective Factors on the Performances of the Recreational Trap Shooters: An Amateur Competition Sample in Afyonkarahisar City. International Journal of Recreation and Sport Science, 5(1); 63-71.

\section{INTRODUCTION}

As a sport, Running Target Shooting requires good balance, anticipation, and eye-hand coordination from the shooter (Viitasolo et al., 1999). Clay Target Shooting is a recreational and competitive activity where participants, using shotguns, attempt to break clay disks (also called clay pigeons, no longer made from clay, but compressed chalk and pitch).

From different situations, targets are randomly thrown into the air at different angles by the machines. There are three major disciplines of competitive clay target shooting which are named; Skeet Shooting, Trap Shooting, and Sporting Clays (Musso et al., 2016).

The continued popularity of target shooting has the potential for exposing a large, diverse population to lead. At a range, exposed individuals include employees such as target shooting instructors and maintenance workers; people who are undergoing work-related training such as law enforcement officers and trainees, security guards, and correctional officers; and people who enjoy target shooting as a hobby, including competitive shooters of all ages (Prince and Horstman, 1993; Shannon, 1999; Lynn et al., 2005; Gelberg and DePersis, 2009).

Youth are encouraged to participate in target shooting activities at local indoor and outdoor shooting ranges, or informal rural venues such as farms and ranches under the mentorship of adult shooters. These events typically have bystanders and spectators nearby the shooters (Meinke et al., 2014).

Indeed, hunters exhibit no association between hunting rifles and aggression, implying that they classify these rifles as working tools and not weapons (Bartholow et al., 2005). The same could also be true for target-shooters who might represent their weapon as a sports instrument or for people carrying guns to protect themselves rather than to act aggressively (Erle et al., 2017).

\section{METHOD}

\section{Sample}

The demographic data of the competitors is obtained via a questionnaire at an amateur trap competition at Afyonkarahisar city in Turkey between the dates 16-17 July 2019. The questionnaire is applied to 70 competitors; however, because of some wrong and unfilled questions, the final analyses are applied to over 62 competitors. As the rule of the competition, performances of shooters are measured over ten shots, and the performance results are obtained from the arbitrator reports at the end of the competition.

\section{Statistical analysis}

Chi-Squared Automatic Interaction Detection (CHAID) analysis is applied to determine the effective factors on the performances of trap shooters. Related to the results of the CHAID analysis, the relations of the levels of the categorical variables with the shooters' performances are examined via Multiple Correspondence Analysis.

CHAID proceeds in steps. First it finds the best partition and then the predictors are compared and the best one chosen. The data are subdivided according to this chosen predictor. To produce further subdivisions for analysis, each of these subgroups are reanalyzed independently. The type of each predictor determines the permissible groupings of its categories, to build the contingency table with the highest significance level according to the Chi-squared test (Kass, 1980; Saracli et al., 2014).

Multiple Correspondence Analysis (MCA) is a multivariable statistical method, to describe, explore, summarize and visualize the results in two or more dimentions. (Saracli and Gazeloğlu, 2018; Blasius and Greenacre, 2014). 


\section{RESULTS}

Performances of the trap shooters related to their demographic features are given in Table1.

Table 1 indicates that most of the participants are graduated from high school, between the ages 30-40, 1-3 years experienced, use their right eye and right hand while shooting, smoking a cigarette but not drinking alcohol, married, and have 1000-3000 TL monthly income, between 80-99 kg weight and between 175-184 cm height.

When we examine the descriptive statistics of the Trap Shooters given in Table 1, as the education level, those who graduated from secondary school have the greatest performance score with the mean 6.18 shots among other demographic features. It can also be seen that greatest performance of the trap shooters for the categories are; According to age category, Trap Shooters who are between 30-40 years old has the mean score of 5.57, who are experienced 4-6 years has the mean score 5.92, who are left handed has the mean score 6.13 , who use their both eyes has the mean score 6.14, who use alcohol has the mean score 5.91, who use cigarette has the mean score 5.22, who are single has the mean score 5.25 and whose income are $5001 \mathrm{TL}$ and higher has the mean score 6.33 .

The result of the CHAID Analysis is given in Figure 1. As it can be seen from Figure 1, even all of the categorical variables are included in the analysis to determine their effects on the dependent categorical variable "performance", only statisticaly significant variables are in the Figure. As Loze et al. (2001) mentioned, similarly in this study, Numerically high performance is considered over 10 shots.

Figure 1 indicates that the most effective factor on the performance of trap shooters is alcohol usage. The average shootings for alcohol users and non-alcohol users are 5 and 4 respectively. Within the trap shooters who use alcohol, cigarette usage found the effective factor, and those who both use alcohol and cigarette, the average shooting is 7 while it's 5 for the shooters who use alcohol but no cigarette. Height of the trap shooters within who both use alcohol and cigarette found the last effective factor and as an average, shooters whose height is equal or less than $173 \mathrm{~cm}$, shoot 7 while it's 6 for those whose height is greater than $173 \mathrm{~cm}$.

On the other hand, within the trap shooters who do not use alcohol, experience found the effective factor and the average shots for the competitors experienced 1-3 years, 4-6 years and much than 6 years are 4,6 and 1 respectively. Cigarette usage is again found the effective factor on the trap shooters, who don't use alcohol and experienced 4-6 years. Within this category, the average shots are 5 for those who use cigarettes and 8 for those who do not use cigarettes. 
Karagöz Ş., Saraçlı S., Dinç H. \& Tunca B. (2021). Examination of the Effective Factors on the Performances of the Recreational Trap Shooters: An Amateur Competition Sample in Afyonkarahisar City. International Journal of Recreation and Sport Science, 5(1); 63-71.

Table 1. Frequencies of Demographic Variables and Performance Statistics.

\begin{tabular}{|c|c|c|c|c|}
\hline \multirow{2}{*}{ Variable } & \multirow{2}{*}{ Level } & \multirow{2}{*}{$\mathbf{n}$} & \multicolumn{2}{|c|}{ Performance } \\
\hline & & & Mean & S.Dev. \\
\hline \multirow{5}{*}{ Education } & Primary & 14 & 4.36 & 1.78 \\
\hline & Secondary & 11 & 6.18 & 1.89 \\
\hline & High & 20 & 5.30 & 2.30 \\
\hline & University & 13 & 4.54 & 2.03 \\
\hline & MS or PhD & 4 & 6.00 & 0.82 \\
\hline \multirow{3}{*}{ Age } & $18-29$ & 12 & 5.08 & 1.68 \\
\hline & $30-40$ & 37 & 5.57 & 1.95 \\
\hline & $41+$ & 13 & 3.92 & 2.29 \\
\hline \multirow{3}{*}{ Experience } & 1-3 Years & 28 & 4.96 & 2.19 \\
\hline & 4-6 years & 24 & 5.92 & 1.59 \\
\hline & $7+$ years & 10 & 3.70 & 1.95 \\
\hline \multirow{3}{*}{ Eye } & Right & 48 & 5.10 & 2.08 \\
\hline & Left & 7 & 4.29 & 2.21 \\
\hline & Both & 7 & 6.14 & 1.46 \\
\hline \multirow{2}{*}{ Left hand } & Yes & 8 & 6.13 & 1.55 \\
\hline & No & 54 & 4.98 & 2.09 \\
\hline \multirow{2}{*}{ Alcohol usage } & Yes & 23 & 5.91 & 1.65 \\
\hline & No & 39 & 4.67 & 2.14 \\
\hline \multirow{2}{*}{ Cigarette Usage } & Yes & 37 & 5.22 & 2.12 \\
\hline & No & 25 & 5.00 & 1.98 \\
\hline \multirow{2}{*}{ Marital Status } & Single & 12 & 5.25 & 1.96 \\
\hline & Married & 50 & 5.10 & 2.09 \\
\hline \multirow{6}{*}{ Income } & $500-1000$ & 6 & 5.33 & 1.51 \\
\hline & $1001-2000$ & 22 & 5.05 & 1.89 \\
\hline & $2001-3000$ & 21 & 4.95 & 2.58 \\
\hline & $3001-4000$ & 2 & 5.50 & 0.71 \\
\hline & $4001-5000$ & 8 & 5.13 & 1.96 \\
\hline & 5001 and + & 3 & 6.33 & 1.53 \\
\hline \multirow{3}{*}{ Weight } & $55-79 \mathrm{~kg}$ & 22 & 4.91 & 2.06 \\
\hline & $80-99 \mathrm{~kg}$ & 30 & 5.33 & 2.02 \\
\hline & 100 and + & 10 & 5.00 & 2.26 \\
\hline \multirow{3}{*}{ Height } & $160-174 \mathrm{~cm}$ & 26 & 5.19 & 2.34 \\
\hline & $175-184 \mathrm{~cm}$ & 29 & 5.10 & 1.92 \\
\hline & 185 and + & 7 & 5.00 & 1.63 \\
\hline
\end{tabular}


Karagöz Ş., Saraçlı S., Dinç H. \& Tunca B. (2021). Examination of the Effective Factors on the Performances of the Recreational Trap Shooters: An Amateur Competition Sample in Afyonkarahisar City. International Journal of Recreation and Sport Science, 5(1); 63-71.

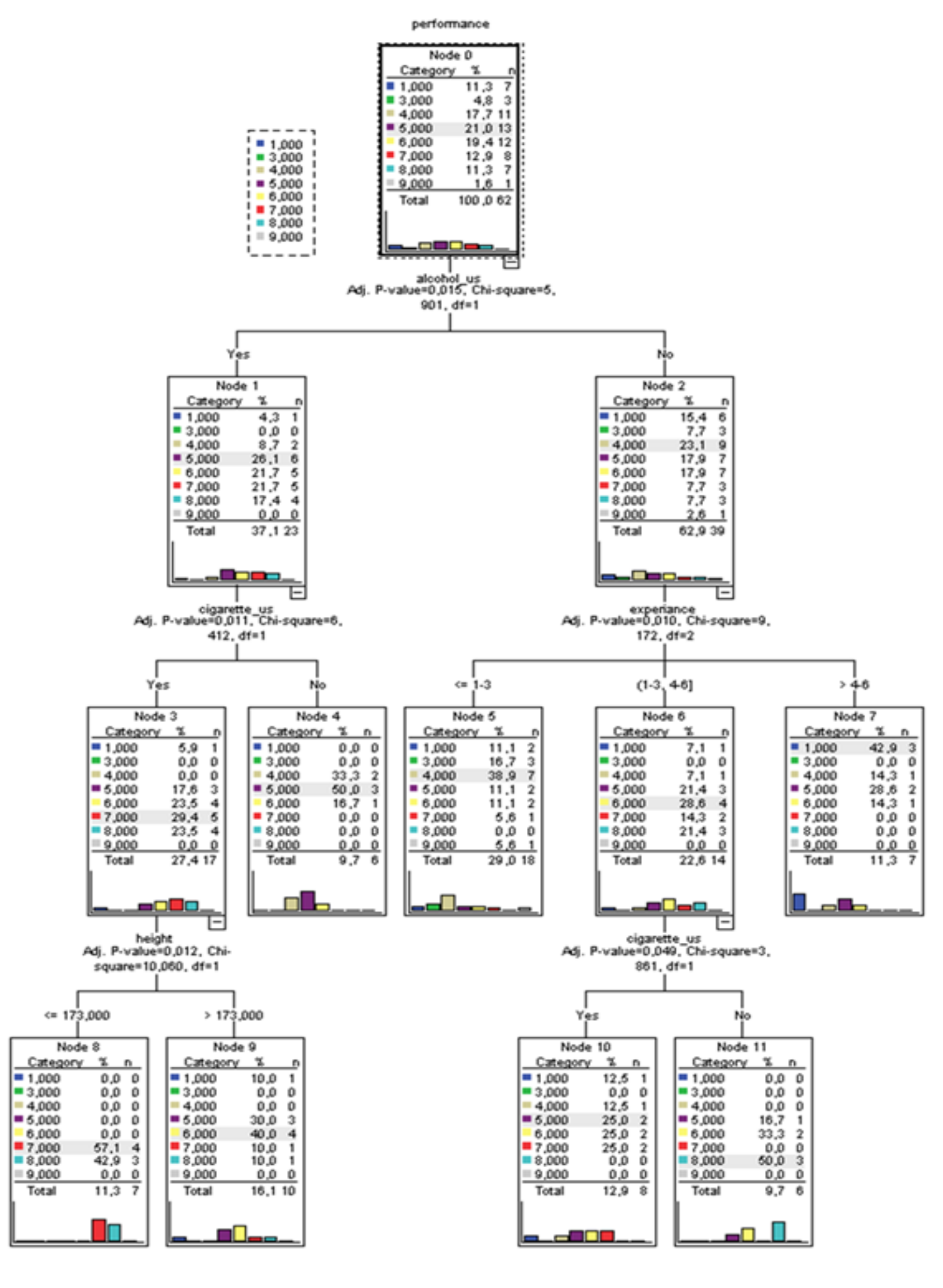

Figure 1. Effects of demographic factors on the performances of trap shooters. 


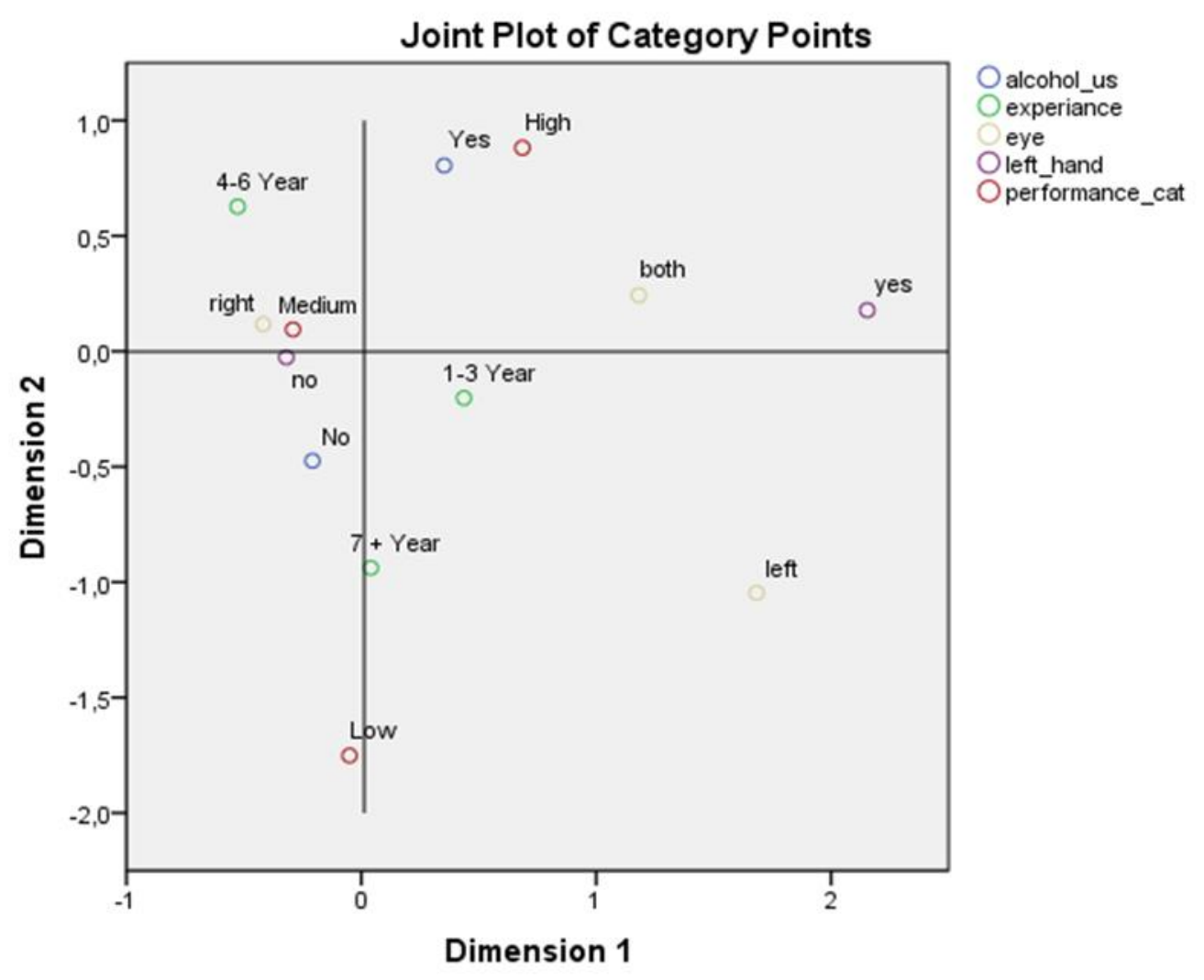

Variable Principal Normalization.

Figure 2. Relations between categorical variables and performances of trap shooters

Besides several harmful effects of alcohol usage, it's a known fact that correct dosage of alcohol has some beneficial effects for some individuals. For example, as the results of their studies, Steele and Josephs (1990) and Rothman et al. (2012) mentioned that alcohol could reduce self-consciousness and shyness, making it easier for people to act without inhibition. At the same time, it can impair judgment and make people do things that they end up regretting (Y1ldirim et al. 2020) Agarwal (2002) and Gronbek (2009) also emphasized that moderate alcohol intook may be effective in reducing stress. Emotional shock or anger trigger the sympathetic nervous system releasing epinephrine or norepinephrine leading to either a rise in blood pressure and may ultimately lead to cardiac arrhythmia and sudden death. The professional trap shooters that we made an interview during the competition also emphasized that drinking a glass of alcohol relax them for a better shot by reducing the handshake and it is related to the tranquilizer effect of alcohol.

Professional shooters emphasize that using both eyes (which enhances the field of view), experience, a correct position, and 
Karagöz Ş., Saraçlı S., Dinç H. \& Tunca B. (2021). Examination of the Effective Factors on the Performances of the Recreational Trap Shooters: An Amateur Competition Sample in Afyonkarahisar City. International Journal of Recreation and Sport Science, 5(1); 63-71.

concentration is much important and increases the performance of shoting.

Considering this idea a multiple correspondence analysis is also applied to the data set to see the relations among the levels of these categorical variables and the performances of trap shooters. The results of the multiple correspondence analysis are given in Figure 2.

Similar to the results of CHAID analysis, results of multiple correspondence analysis, given in Figure 2, indicate thoses trap shooters whose performances are categorized as high are those who use alcohol, less than 7+ years experienced, using both eyes and left hand. Whose performances are medium are the shooters using their right hand, right eye, 4-6 year experienced and not using alcohol. The trap shooters having low performances are the shooters who are experienced 7 or more years, do not use alcohol, use their right hand and use either their left or right eye while shooting.

\section{DISCUSSION AND CONCLUSION}

In recent years in Turkey, trap shooting is becoming one of the most famous sport. New platforms are building in different cities of the country, and concerns for young and female individuals are also increasing. In this study both to emphasize the importance of this sport and to determine the effective factors on trap shooting performance, a data set is collected from the amateur competition and analyzed via multivariable statistical techniques. Results of the study indicate that even physical factors are effective on the performance, mental factors are also effective on the scores of the shooters.

When we examine similar studies; Share et al. (2009) aimed to determine the effects of two doses of caffeine on shooting performance, reaction time, and target tracking times in the sport of clay target shooting, and results of their study, indicate that caffeine does not provide performance benefits to elite performers of clay target shooting in the double trap discipline. In their study, Dadswell et al. (2016) aimed to identify how performance-related variables (a) changed within each shooting series and (b) changed between each shooting series. In conclusion, they mentioned that neither time constraints nor the effects of each running phase caused any significant changes in combined event shooting performance. In their study, Mets et al. (2003) examined the reproducibility of professional target shooters and as a result, they concluded that the most experienced and educated shooter observed the shooting performance most reproducibly among the others.

Professional trap shooters emphases that combination of mental, physical, physiological, and environmental conditions affect the performances of trap shooting. According to their experiences, besides a well calibrated gun; correct position, well concentration, quiet environment, and physiologically well adaptation are the most effective factors on performance. As a conclusion, in this study, we aimed to determine the effects of the individual features and the results of the study have confirmed some of the effective factors on trap shooting performances similar to the other studies.

Funding: The authors declare that they received no financial support for this study.

Acknowledgments: The authors would like to thank each of the competitors for their kind contribution to the study.

Conflicts of Interest: The authors declare no conflict of interest. 
Karagöz Ş., Saraçlı S., Dinç H. \& Tunca B. (2021). Examination of the Effective Factors on the Performances of the Recreational Trap Shooters: An Amateur Competition Sample in Afyonkarahisar City. International Journal of Recreation and Sport Science, 5(1); 63-71.

\section{REFERENCES}

Agarwal, D. P.(2002). Cardio protective effects of light-moderate consumption of alcohol: a review of putative mechanisms. Alcohol and Alcoholism, 37 , 409-15. doi.org/10.1093/alcalc/37.5.409

Bartholow, B. D., Anderson, C. A., Carnagey, N. L. \& Benjamin, A. J. Jr. (2005). Interactive effects of life experience and situational cues on aggression: The weapons priming effect in hunters and nonhunters. Journal of Experimental Social Psychology, 41, 48-60. https://doi.org/10.1016/j.jesp.2004.05.00 5

Blasius, J. \& Greenacre, M. (2014). Visualization and verbalization of data. Florida: CRC Press, Taylor and Francis Group.

Bonke, D., \& B. Nickel. (1989). Improvement of Fine Motoric Movement Control by Elevated Dosages of Vitamin B1, B6, B12 in Target Shooting. International Journal for Vitamin and Nutrition Research Supplement, 30, 198-204.

Dadswell, C., Payton C., Holmes, P. \& Burden, A. (2016). The effect of time constraints and running phases on combined event pistol shooting performance. Journal of Sports Sciences, 34(11), 1044-1050. DOI: 10.1080/02640414.2015.1088163.

Erle, T. M., Barth N., Kalke, F., Duttler, G., Lange, H., Petko, A. \& Topolinski S. (2017). Are Target-Shooters More Aggressive Than the General Population?. Aggressive Behavior, 43, 3-13.

Gelberg, K. H. \& DePersis, R. (2009). Lead Exposure Among Target Shooters.
Archives of Environmental \& Occupational Health, 64(2), 115-120.

Gronbek, M. (2009). The positive and negative health effects of alcohol and the public health implications. Journal of Internal Medicine, 265(4), 407-420.

Kass, G.V. (1980). An Exploratory Technique for Investigating Large Quantities of Categorical Data. Applied Statistics, 29(2), 119-127.

Loze, G.M., Collins, D. \& Holmes, P. S. (2001). Pre-shot EEG alpha-power reactivity during expert air-pistol shooting: A comparison of best and worst shots. Journal of Sports Sciences, 19(9), 727-733. DOI: $10.1080 / 02640410152475856$.

Lynn, T., Arnold, S., Wood, C., Castrodale, L., Middaugh, J. \& Chimonas, M. (2005). Lead exposure from indoor firing ranges among students on shooting teams --Alaska, 2002-2004. Morb Mortal Wkly Rep, 549, 577-579.

Meinke, D. K., Murphy, W. J., Finan, D. S., Lankford, J. E., Flamme, G. A., Stewart, M., Soendergaard, J. \& Jerome, T. W. (2014). Auditory risk estimates for youth target shooting. International Journal of Audiology, 53, 16-25.

Mets, T., Viitasalo, J., Mononen, K. \& Konttinen, N. (2003). Reproducibility of Coaches' observations in running target shooting performance. Kinesiology, 35(2), 201-209.

Musso, F., Richelieu, A. \& Francioni, B. (2016). Making small sports clubs manageable and economically sustainable - a study on clay target shooting in Italy. Managing Sport and Leisure, 21(5), 283-299. doi.org/10.1080/23750472.2016.127379 1. 
Karagöz Ş., Saraçlı S., Dinç H. \& Tunca B. (2021). Examination of the Effective Factors on the Performances of the Recreational Trap Shooters: An Amateur Competition Sample in Afyonkarahisar City. International Journal of Recreation and Sport Science, 5(1); 63-71.

Prince, T.S. \& Horstman, S.W. (1993). Case study at a college rifle range: the effect of a new ventilation system on air and blood lead levels. Appl Occup Environ Hyg, $\quad$ 8, 909-911. Doi:10.1080/1047322X.1993.10388223

Rothman, E. F, Reyes, L. M., Johnson, R. M. \& LaValley, M. (2012). Does the Alcohol Make Them Do It? Dating Violence Perpetration and Drinking Among Youth, Epidemiologic Reviews, 34(1), 103-119. https://doi.org/10.1093/epirev/mxr027.

Saracli, S., Başar, M. A., Erdoğmuş Cengiz, B. \& Gazeloğlu, C. (2014). Effects of Maslow's needs and SocioDemographical Factors on Motivational Needs in a School Context. The Journal of Academic Social Science Studies, 25, 315-328. Doi: 10.9761/JASSS2407.

Saracli, S., Gazeloğlu, C. (2018). Statistical analysis of vehicle driver behaviors. Journal of Organizational Behavior Research, 3(1), 197-204.

Shannon, M. (1999). Lead poisoning in adolescents who are competitive marksmen. $N$ Engl J Med., 341, 852. Doi: 10.1056/NEJM199909093411118
Share, B., Sanders, N. \& Kemp, J. (2009). Caffeine and performance in clay target shooting. Journal of Sports Sciences, 27(6), 661-666. DOI:10.1080/02640410902741068.

Steele, C. M., \& Josephs, R. A. (1990). Alcohol myopia: Its prized and dangerous effects. American Psychologist, $\quad$ 45(8), 921-933. doi.org/10.1037/0003-066X.45.8.921.

Viitasolo, J.T., Era, P., Konttinen, N., Mononen, H., Mononen, K., Norvapalo, K. \& Rintakoski, E. (1999). The Posture Steadiness of Running Target Shooters of Different Skill Levels. Kinesiology, 31(1), 18-28.

Yildirim, I., Dogan, I., Isik, O., Yildirim, Y., \& Karagoz, S. (2020). Investigation of the relationship between basal metabolic rate and body composition in young adults using Cha1d analysis. Progress in Nutrition, 22, 5-10. 